\title{
Influence Of Parents Sources And Level Of Income On Teenage Pregnancies In Public Primary Schools In Nandi South-Sub County
}

\author{
Eunice Malesi $^{1}$, Prof. Lewis Ngesu ${ }^{2}$, Dr. Alice Masese ${ }^{3}$ \\ ${ }^{1}$ Student Master of Education, University of Nairobi \\ ${ }^{2}$ Lecturers, Department of Educational Foundations, University of Nairobi \\ DOI: 10.29322/IJSRP.11.11.2021.p11941 \\ http://dx.doi.org/10.29322/IJSRP.11.11.2021.p11941
}

\begin{abstract}
The rate of teenage pregnancy among the school going girls in both primary and secondary schools in Kenya has been on the increase in the past few years. Each year the media highlights the high number of girls failing to sit their final primary (KCPE) or secondary school examinations (KCSE) or doing the exams when expectant. The present paper aimed to establish the influence of parents sources and level of income on teenage pregnancies in public primary schools in Nandi South-Sub County. The study was guided by The Social Learning Theory which was propounded by a Canadian psychologist in the 1960s. The study adopted a descriptive research design using both quantitative and qualitative approaches. This study design will enable the researcher to collect data from the population on their perceptions and attitudes while determining their current status in regard to the study topic and the variables of the study on the research topic. Nandi South SubCounty is one of the 5 sub counties found in Nandi County, North Rift of Kenya, (IEBC 2020). The target population of this study comprised of teenage pupils (both boys and girls) in class 8 and class 7 , teenage mothers, class teachers, education officers and head teachers, who are the recognized administrators of schools. According to the Ministry of Education, Nandi South sub-county education office, there are a total of 72 public primary schools in the area with a total of 14, 855 class 7 and 8 pupils, (boys, 7,963 and girls 6,892 ). This study used two sets of questionnaires and in interview to collect data. Majority of the respondents (59.1\%) said that it influences academic performance to either a very great extent or to a great extent. The mean score of descriptive statistics was 2.65 (std dev $=0.939$ ) which had been coded 'a great extent' on the Likert scale.
\end{abstract}

Index Terms- Teenage Pregnancy, parental sources of income, Primary schools, Kenya

\section{INTRODUCTION}

$\mathrm{G}$ lobally, teenage pregnancy has been on the increase. This is according to a World Health Organization report (WHO, 2019) that estimated that 21 million girls in their teenage hood become pregnant each year worldwide. Out of this number, 12 million give birth while the rest either terminate the pregnancy or die. The report adds that of these pregnancies, 10 million are unintended and that 2.5 million births occurred among girls under the age of 16 years and below. The report further indicates that 5.6 million abortions occur annually out of which 3.9 million are unsafe thus contributing to high maternal mortality, morbidity and long-lasting health problems. The WHO, (2019) further adds that pregnancy and child birth complications are the leading cause of death among 15- to 19-year-old girls globally.

The World Health Organization (2019) report notes further that, globally, adolescent fertility has declined from 56 births per 1,000 adolescent women in 2000 to 45 births in 2015 and 44 births in 2019. In the European nations, the adolescent pregnancy is approximately averaging at 17 per 1000 girls with Tajikistan having the highest number of 54 per 1000 teenagers with San Marino recording the lowest with an average of one case per 1000 teenagers. However, in the sub-Saharan Africa, the level of teenage pregnancy is very high at an average of 101 births per 1000 adolescent women, Sustainable Development Goals Knowledge Platform, (SDGKP, 2019). This is the highest birth rate compared to other parts of the world.

The United Nations Department of Economic and Social Affairs (UNDESA) Statistics Division, (2017) notes that the majority of adolescent births occur in low and middle-income countries with West and Central Africa registering the highest birth rates and East Asia, the lowest. The report further adds that within countries, adolescent births are more likely to occur among poor, less educated and rural populations. In these low- and middle-income countries, adolescent girls are under pressure to marry and bear children early because of limited educational and employment opportunities or due to inability to access or low knowledge on how to use contraceptives, (SDGKP, 2019). Further, sexual violence was cited as another cause of unintended or unwanted pregnancy with a third of the teenage pregnancies in some being as a result of sexual coercion.

According to Wado, Sully \& Mumah, (2019), nearly half of the unsafe abortion cases in sub-Saharan Africa occur among adolescents and women under the age of 25 years. Among The nations with the highest rates are: Nigeria, Uganda, Tanzania and Democratic Republic of Congo. Omoro, Simeone, Otieno, Mbeda, Penelope, Hayes \& Gust (2018) contend that the high level of teenage pregnancy is caused by such factors such as poverty and gender inequality where the society prefers schooling boys over girls. The scholars cite Kenya as a case of which adolescent girls make up nearly $17 \%$ of post abortion cases and account for $45 \%$ of severe abortion related complications treated in health. 
This information is corroborated by the Ministry of Health Statistics of 2013 on the incidence of unsafe abortions in Kenya. Loaiza, (2013) notes that Kenya is among the top five countries in the world with the greatest projected increase in teenage pregnancy over the next 20 years.

The Kenya Demographic and Housing Survey report (KNBS, 2014) indicate that nearly a quarter of Kenyan women give birth by the age of 18 , and nearly half by the age of 20 years. The report further indicates that one in every five girls between 15-19 years has begun childbearing or already has a child (KDHS 2014). The report by United Nations Population Fund (UNFPA, 2018) further indicated that the birth rate for Kenya's adolescents is 96 per 1000 women, and that $15 \%$ of adolescent girls have given birth, and that nearly $3 \%$ are pregnant with their first child. The report further adds that nearly 378,400 adolescent girls in Kenya aged between 10 and 19 years became pregnant between July 2016 and June 2017. Of the total figure, 28,935 girls were between 10 and 14 years while 349,465 girls were between 15 to 19 years. (UNFPA, 2018).

\section{StATEMENT OF THE PROBLEM}

The rate of teenage pregnancy among the school going girls in both primary and secondary schools in Kenya has been on the increase in the past few years. Each year the media highlights the high number of girls failing to sit their final primary (KCPE) or secondary school examinations (KCSE) or doing the exams when expectant. According to the United Nations for Population Fund Agency (UNFPA, 2018), teenage pregnancy in Kenya stands at $18 \%$ though the situation varies across counties with some counties having higher rate than others. This is a national social crisis that needs to be addressed urgently.

The problem of teenage pregnancy is equally highly prevalent in Nandi South Sub County as it is in other counties with girls Conceptual Framework dropping out of school as from age of 13 years. Much of the information available on incidence of teenage motherhood gives a national picture in Kenya though some studies have been done in other regions such as Nyanza and Coast with $27 \%$ and $25.7 \%$ respectively, Awuor, (2018). The Government has tried to address this problem by encouraging young mothers to go back to school with clear admission policy guidelines. Further, the government has sensitized teenage girls and youth in general about teenage pregnancies and dangers associated with the vice. However, despite these efforts the problem has persisted with no cure in place. The high number of teenage pregnancy reveals that this is an urgent matter that requires attention from the government, other stakeholders and the community at large hence the need for a study. Therefore, this study intends to fill this gap by establish the influence of parents sources and level of income on teenage pregnancies in public primary schools in Nandi South-Sub County.

\section{OBJECTIVE OF THE STUDY}

To establish the influence of parent's sources and level of income on teenage pregnancies in public primary schools in Nandi South-Sub County.

\section{Research question}

How do the parents sources and level of income influence the prevalence of teenage pregnancy in public primary schools in Nandi Sub County?

\section{Figure 1.1 shows the interaction between teachers' self-efficacy and performance appraisal}

\section{Independent Variable}

\begin{tabular}{|l|}
\hline Parent's source and \\
Level of income \\
-Formal and informal \\
Employment-type of job \\
-Family Poverty levels \\
-Amount of family income
\end{tabular}

Dependent variable

Figure 1.1: Conceptual Framework

Source: Author conceptualization (2021)

\section{EMPIRICAL LITERATURE}

The Social Learning Theory was propounded by a Canadian psychologist in the 1960s and 1970s by Albert Bandura (1977) but later developed to the Social Cognitive Theory, (SCT) (1986). This theory has been chosen because it interrogates how people acquire character and behaviour in a given environment and social units. These social units include but not limited to the home and the school environment. The theory posits that learning is "the reciprocal interaction between cognitive, behavioral and environmental determinants of human behavior" (Bandura, 1977). The theory defines 3 main processes involved in learning: direct experience, indirect experience and modelling or observational 
experience. These three processes are the ways in which people acquire and maintain behaviour. The theory suggests that human behaviour is learned and acquired from the environment and that they are influenced by the social context. The Social Learning Theory (SLT) states that people learn from one another through observations, imitation and modelling. According to Awuor, (2018) the SLT proposes that human interaction is an interaction of personal, behavioural and environmental factors which are the social norms and influence from others surrounding an individual. The Social Learning is very important in the study of teenage pregnancy because it examines the role of parents and other family members in influencing the behaviour of a child. In applying the SLT to adolescent pregnancy, the major component would be the modelling one because teenagers learn mostly through observational learning. The teenage girl will most definitely observe and imitate the behaviour of parents or older siblings. If the parents and older siblings are good roles models then the younger child is mostly likely to exhibit good behaviour like that of the parent and vice versa.

According to Shiateya, (2016), family dysfunctions or absence of parents has a direct bearing on adolescent sexuality and pregnancy. When both parents are present, it acts as a protective shield against girl child sexual exploitation resulting into teenage pregnancy. A study conducted by Muthoni and Mutua, (2019) in Nzambani Ward in Kitui County found out that girls who did not live with both their parents were more likely to begin having sex at a much younger age than those who were living with both parents. The presence of the father ensures that girls are protected from outside predatory men while the presence of the mother helps protect the girls from some predatory fathers who sexually abuse their daughters.

According to Muthoni and Mutua, (2019), teenage pregnancy is exacerbated by some parents who neglect their children by relegating them to the care of their grandparents and other relatives. The researchers further observe that quite a number of children especially teenage girls lack parental supervision because their mothers got married elsewhere thus abandoning them. Grandparents are not adequately equipped to supervise and guide teenage girls.

Matheka (2012) asserts that teenage girls from single households or those with missing fathers have a greater risk of becoming pregnant than those with fathers. Additionally, a teenage who is raised in a family where there is domestic violence can make it begin to think of ways of escaping from this home torture leading to early pregnancy and marriage especially if her needs have been neglected. This position is supported by the National Gender and Equality Commission that conducted a study in Coastal Belt of Kenya in 2016 where it found out high level of single mothers raising children due to separation or absent fathers. Many girls are living with their maternal grandmothers which exposes them to sexual exploitation because most of them cannot afford basic needs. The grandmothers are also not strict in implementing home discipline measures to the teenage girls.

Moreover, parents should be good roles to their children. It is noted that some parents engage in risky sexual behaviour such as having multiple sexual partners or even extra-marital affairs in the eyes of the teenagers. This can be a trigger factor that push teenagers into early sexual encounter which can lead to teenage pregnancy, Musonga (2014). This position is supported by Njoka, (2016) who conducted a study in Kilifi County on the causes of teenage pregnancy and established that poor parenting was a major cause. There were many single mothers, some of whom were engaging in prostitution thus exposing their children to early sex. It was discovered that some of these single mothers brought men into their small house and could have sex while children were hearing or seeing it.

A study conducted by Ikamari, Ochako \& Chimaraoke (2013) on the prevalence and determinants of unintended pregnancy among women in Nairobi, Kenya found out that a woman's marital status had a correlation with the teenage pregnancy and that girls from single mothers were at a much higher risk of getting pregnant than those who had fathers.

\section{RESEARCH METHODOLOGY}

The study adopted a descriptive research design using both quantitative and qualitative approaches. This study design will enable the researcher to collect data from the population on their perceptions and attitudes while determining their current status in regard to the study topic and the variables of the study on the research topic. Nandi South Sub-County is one of the 5 sub counties found in Nandi County, North Rift of Kenya, (IEBC 2020).

The target population of this study comprised of teenage pupils (both boys and girls) in class 8 and class 7, teenage mothers, class teachers, education officers and head teachers, who are the recognized administrators of schools. According to the Ministry of Education, Nandi South sub-county education office, there are a total of 72 public primary schools in the area with a total of 14 , 855 class 7 and 8 pupils, (boys, 7,963 and girls 6, 892). The study used simple random sampling technique to select pupils who were respondents of the study drawn proportionately from different strata. This study used two sets of questionnaires and in interview to collect data.

\section{STUdy RESUlts}

The results indicate that the response rate $75.3 \%$ which is considered good since it is above the $70 \%$ threshold recommended by Mugenda and Mugenda (2003). Class 7 and 8 pupils were the majority of the respondents at $87.6 \%$ while class teachers comprised of $9.5 \%$ of the respondents. The least category of respondents were head teachers at $2.9 \%$ of the total respondents.

\section{Descriptive statistics of extent to which parent's level of income influences prevalence of teenage pregnancy}

The study asked respondents to state the extent to which the level of parents' education influenced the prevalence of teenage pregnancy. The lickert scale was coded as follows: 1-low extent, 2-moderate extent, 3-a great extent, 4- a very great extent. The results are as shown in Table 4.1. 
Table 4.13 Extent to which the parent's level of income influence teenage pregnancy

\begin{tabular}{lll}
\hline Responses & Frequency & Percent \\
\hline Low extent & 37 & 13.5 \\
Moderate extent & 75 & 27.4 \\
A great extent & 110 & 40.1 \\
A very great extent & 52 & 19.0 \\
Total & $\mathbf{2 7 4}$ & $\mathbf{1 0 0 . 0}$ \\
\hline
\end{tabular}

Source: Field Study (2021)

The results indicate that $13.5 \%$ of the respondents were of the view that the level of parent's income influences the rate of teenage pregnancy to a low extent while $27.37 \%$ thought it was to a moderate extent. Those respondents who were of the opinion that it influences to a great extent were $40.15 \%$ whereas those who said to a very great extent were $18.98 \%$.
In order to assess the influence of a number of sub themes related to the parent's level and source of income, the respondents were given statements against which they were to rate their level of agreement or disagreement on a lickert scale of 4 grades as follows: 4- Strongly agree; 3-agree; 2-disagree; 1-strongly disagree. The results of the study are as shown in Table 4.2

Table 4.2: Statements on the influence of parent's source and income level on teenage pregnancy

\begin{tabular}{lllll}
\hline Statement & $\mathbf{n}$ & Mode & Mean & Std. Dev \\
\hline $\begin{array}{l}\text { Most parents are not financially stable and therefore unable to } \\
\text { provide all the basic needs for their children }\end{array}$ & 274 & 3 & 2.87 & 0.973 \\
$\begin{array}{l}\text { Some girls solicit for material favours from men in exchange for } \\
\text { sexual favours. }\end{array}$ & 274 & 3 & 2.87 & 0.891 \\
$\begin{array}{l}\text { A girl from a poor background is more likely to become pregnant } \\
\text { than a girl from a well-off family }\end{array}$ & 274 & 4 & 2.98 & 1.041 \\
$\begin{array}{l}\text { Girls from poor families are more likely to be introduced to sex at } \\
\text { a younger age than girls from a well-off families }\end{array}$ & 274 & 4 & 2.99 & 1.016 \\
$\begin{array}{l}\text { The kinds of job parents do significantly influence chances of their } \\
\text { girls becoming teenage mothers }\end{array}$ & 274 & 3 & 2.68 & 1.041 \\
Overall & $\mathbf{2 7 4}$ & & $\mathbf{2 . 8 7 8}$ & $\mathbf{0 . 9 9 3}$ \\
\hline
\end{tabular}

Source: Field Study (2021)

Results from table 4.16 show that majority of the strongly agreed that most parents are not financially stable and there unable to provide all the need for their children. The mean score was 2.87 $(\mathrm{SD}=0.973)$ which translates into 'agree' on the Likert scale. On the question of whether some girls solicit for material favours from men in exchange for sexual favours, the majority of the respondents agree with the statement. The mean was 2.87 and standard deviation 0.891 which implies that most responses were around the mean. On the third question of whether a girl from a poor background is more likely to become pregnant than a girl from a well-off family, the mean score was 2.98 with a standard deviation of 1.041 which implies 'agree' on the Likert scale though the mode of the responses was ' 4 ' which meant that the majority of the responses strongly agreed.

On the fourth question of whether girls from poor families are more likely to be introduced to sex at a younger age than girls from a well-off family, majority of the respondents strongly agreed (mode of 4) though the mean score was 2.99 with a standard deviation of 1.016. Therefore, on the average, the respondents agreed with the statement. The last question tested whether kinds of job parents do have a significant s influence on the chances of their girls becoming pregnant, majority of the respondents agreed with the statement (mode of 3 ) and a mean of 2.68 with a standard deviation of 1.041 .

\section{CONCLUSION}

From the findings, majority of the respondents were of the opinion that parent's source of income influences teenage pregnancy. Majority of the girls occasionally miss school due to lack of basic needs. These findings clearly show that most parents are either subsistence farmers or run small businesses. This implies that the parents are not financially stable. This contributes to teenage pregnancy due to lack of basic needs for the children. Due to low income of parents, some girls solicit for material favors from men in exchange for sexual favors. The study established girls from poor families are more likely to be introduced to sex at a younger age than girls from a well-off family. A parent's level of education has a direct bearing on the disposable incomes and the level of engagement in a child's education journey.

\section{RECOMMENDATION}

Parents should provide basic needs for their children especially girls so that they don't solicit for them from men in 
exchange for sexual favours. It has been established that this is the biggest factor causing girls to be lured into early sex for material gain. Parents should also guide and counsel their children on the importance of education even if they themselves are not very educated. The study noted that the level of parent's education has a direct influence on teenage pregnancy. Educated parents serve as role models to their children unlike the uneducated parents.

\section{REFERENCES}

[1] Adolf, J. (2014) Socio-Economic Factors Affecting Adolescent Mothers' Struggles to Revive their Aspirations in Makete District, Tanzania. Unpublished MA Thesis Sokoine University of Agriculture, Tanzania.

[2] Advocates for Youth (2005). The Facts: Adolescent Sexual and Reproductive Health in Sub-Saharan Africa. Hrttp://advocateforyouth.org/publications/factsheet/fssxrepr.httml

[3] Akella, D. A., \& Jordan, M. A. (2015). Impact of Social and Cultural Factors on Teen Pregnancy. Journal of Health Disparities Research and Practice, 8(1), 41-60.

[4] Anya, K. G. (2013). An Assessment of the Influence of Life Skills Education on Reproductive Health Behaviour of adolescent Girls' in Public schools in Kibera, Nairobi. M.A. Research paper, University of Nairobi.

[5] Awuor, T (2018) Parental involvement in Teenage Pregnancy Prevention in Kenya: A Study of Nyatike Sub-County, Migori County. Unpublished MA Thesis. Rongo University

[6] Babilas, J. (2015) Factors Contributing to High Prevalence of Teenage Pregnancy in Lindi Municipality - Tanzania. Unpublished MA Thesis. Open University of Tanzania

[7] Bandura, A. (1977). Social Learning Theory. Englewood Cliffs, NJ: PrenticeHall.

[8] Chen, C., Ward, C., Williams, K. \& Abdullah, A. (2013). Investigating Risk Factors Affecting Teenage Pregnancy Rates in the United States. European International Journal of Science and Technology Vol. 2 No. 2

[9] Creswell, J.W (2005). Educational Research: Planning, Conducting and Evaluating Quantitative and Qualitative Research, 2nd Edition. Pearson Merrill Prentice Hall

[10] Cronbach, L.J (1984). Essentials of Psychological Testing (4th Edition). New York: Harper \& Row

[11] Ganira, L., N. Inda, P. Odundo and J. Akondo (2015). Early and forced child marriage on Girls' education in Kenya: Constraints, Prospects and Policy. World Journal of Education.

[12] Guttmacher Institute (2014). American Teens` Sexual and Reproductive Health. In

[13] Guttmacher Institute Fact Sheet; Guttmacher Institute: New York, NY, USA

[14] Gyan, C. (2013). The Effects of Teenage Pregnancy on the Educational Attainment of Girls at Chorkor, a Suburb of Accra. Journal of Educational and Social Research. 3(3), 53-60.

[15] Hamilton, B. E., Martin, J. A., Ventura, S. J. (2012) Births: Preliminary data for 2011.

[16] National Vital Statistics Reports. 2011; 57(12).

[17] Ikamari, L., Izugbara, C. and Rhoune, O. R. (2013). Prevalence and determinants of unintended pregnancy among women in Nairobi, Kenya. BMC Pregnancy and Childbirth. 13(69), 1471-2393.

[18] Joyce K, Murungaru K, Lawrence I. \&Elias H., (2015). Perceptions and Barriers to

[19] contraceptive use among adolescents aged 15-19 years in Kenya: A case study of Nairobi.

[20] Kabiru, K. (2014, December). Unmet social needs and teenage pregnancy in Ogbomosho, South-western Nigeria. African Health Sciences, Vol 14( 4).

[21] Kiarie, A.\& Muganbi, M. (2016) Social Media and Teenage Pregnancy among Students In Secondary Schools In Imenti North Sub-County, Meru County, Kenya. International Journal of scientific research and management (IJSRM) Volume 4 Issue 09.

[22] KNBS, (2014) The Kenya Demographic and Housing Survey Report. Kenya National Bureau of Statistics.

[23] Krugu JK, Fraukje Mevissen, Meret Münkel \& Robert Ruiter (2017) Beyond love: a qualitative analysis of factors associated with teenage pregnancy among young women with pregnancy experience in Bolgatanga, Ghana, Culture, Health \& Sexuality, 19:3, 293307, DOI 10.1080/13691058.2016.1216167.

[24] Maninder, S. (2016) Methodology Series Module 3: Cross-sectional Studies. Indian Journal of Dermatology DOI: 10.4103/0019-5154.182410, ResearchGate

[25] Matheka, R, ( 2012) The Boys Get the Pleasure the Girls Get the Pain". The views of teenage girls in Kenya concerning the causes and prevention of teenage pregnancy. Unpublished BA Thesis, Jamk University of Applied Sciences.

[26] Matshoya, Z. (2010) Experiences of Parenting Learners with Regards to Learner Pregnancy Policy. Unpublished MA Thesis, University of the Western Cape.

[27] Miriti, J. (2017b). Sociocultural Norms among Kenyan Pastoralists: Impact on Girls Access to Education Capabilities. A final paper presented to UCL Institute of Education for the Gender, Education and Development Module

[28] Mmari, E. K. (2013, September). Risk and Protective Correlates of Young Women's First Sexual Experiences in Rakai, Uganda. International Perspectives on Sexual and Reproductive Health, Vol. 39( No. 3), 153-162

[29] Mumah, J., Kabiru, C. W., Mukiira, C., Brinton, J., Mutua, M., Izugbara, C., Askew,

[30] I.(2014). Unintended pregnancies in Kenya: a country profile. STEP UP Research Report.Nairobi: African Population and Health Research Center.

[31] Musonga, P. E. (2014). Factors Influencing Girl Child Dropout Rate in mixed

[32] secondary schools in Kenya: A case of Bumula Sub County. MPP Thesis,

[33] University of Nairobi

[34] Mutanana and Mutara, (2015) Factors Contributing to Teenage Pregnancies in a Rural Community of Zimbabwe, Journal of Biology, Agriculture and Healthcare, Journal of Biology, Agriculture and Healthcare

[35] National Gender and Equality Commission, NGEC, (2016) Lost Childhood Drivers of Child Pregnancy in Kenya. NGEC.

[36] Nguyen, H., Shiu, C., \& Farber, N. (2016). Prevalence and Factors Associated with Teen Pregnancy in Vietnam: Results from Two National Surveys. socities, 6(2), 17

[37] Njoka, J. (2016) Teenage Pregnancy in Kenya's Kilifi County: A qualitative study.

[38] Faith to Action Network.

[39] Nyaga, G. (2015) Relationship between Social Support and Self-Esteem among Teenage Mothers Attending Pumwani Maternity Hospital in Nairobi County, Kenya. Unpublished MA Thesis, Kenyatta University.

[40] Nthiga, M \& Kiburi, M. (2019) Factors Contributing To Teenage Pregnancy in Baragoi, Samburu County, Kenya, IOSR Journal of Nursing and Health Science IOSR-JNHS. Volume 8, Issue 3 Ser. VII. PP 26-31

[41] Okigho, C.C., and Speizer, I.S. (2015). Determinants of Sexual Activity and Pregnancy among Unmarried Young Women in Urban Kenya: A CrossSectional Study. PLoS ONE. 10(6), 1-17.

[42] Omari, A. (2016) Teenage Pregnancy in Keeping girls out of School in Kenya. Marie Stopes International, Kenya

[43] Omoro,T., Simone C., Otieno,G., Mbeda, C., Penelope A., Hayes T., Otieno, F. \& Gust, D. (2018) Teen pregnancy in rural western Kenya: a public health issue, International Journal of Adolescence and Youth, 23:4, 399-408, DOI 10.1080/02673843.2017.1402794

[44] Poudel S, Upadhaya N, Khatri RB, Ghimire PR (2018) Trends and factors associated with pregnancies among adolescent women in Nepal: Pooled analysis of Nepal Demographic and Health Surveys (2006, 2011 and 2016). PLoS ONE 13(8): e202107.https://doi.org/10.1371/journal. pone.0202107

[45] Qolesa, S. (2017) Factors Influencing Teenage Pregnancy in Heidedal Location, Mangaung District. Unpublished MPH Thesis, University of the Western Cape.

[46] Raj, D., Rabi B., Amudha P., Edwin T. \& Glyn, C.(2010) Factors associated with teenage pregnancy in South Asia: a systematic review . Www.Hsj.Gr Health Science Journal Volume 4, Issue 1

[47] Rutaremwa, G. (2013). Factors Associated with Adolescent Pregnancy and Fertility in

[48] Uganda: Analysis of the 2011 Demographic and Health Survey Data. American Journal of Sociological Research, 3(2), 30-35.

[49] Shiateya,N. (2016) Factors contributing to teenage fertility in coastal 
[50] Kenya, a case of Mombasa County. Unpublished MA Thesis. University of Nairobi.

[51] UN DESA,(2017) Population Division. World Population Prospects: The 2017 Revision, DVD Edition. New York: UN DESA.

[52] UN DESA, (2017) Statistics Division. SDG Indicators: Global Database. New York: UN DESA.

[53] UNFPA (2015). Girlhood, not motherhood: Preventing adolescent pregnancy. New York: UNFPA

[54] UNICEF. (2018) Ending child marriage: Progress and prospects. UNICEF

[55] UNFPA, The Power of Choice. United Nations for Population Fund Agency.

[56] Wado, D., Sully, A. \& Mumah, N. (2019) Pregnancy and early motherhood among adolescents in five East African countries: a multi-level analysis of risk and protective factors. https://doi.org/10.1186/s12884-019-2204-z
[57] WHO, (2015) Global health estimates: deaths by cause, age, sex, by country and by region, 2000-2015. Geneva: WHO; 2016

[58] World Health Organization, WHO, (2019) Adolescent Pregnancy. WHO

\section{AUTHORS}

First Author - Eunice Malesi, Student Master of Education, University of Nairobi

Second Author - Prof. Lewis Ngesu, Lecturers, Department of Educational Foundations, University of Nairobi

Third Author - Dr. Alice Masese, Lecturers, Department of Educational Foundations, University of Nairobi 